tion is growing too large, yet you make no attempt to examine the question "How large is too large?". It undoubtedly is true that it is much harder than it used to be for people to enjoy the beaches in summer; city streets are certainly more crowded; and the pressure of industry on the environment is obvious to all. Perhaps it is time the problem of the optimal size of Britain's population was examined.

Although the birth rate has fallen since 1966 , you admit that this is likely to be reversed in the next few years. The fact that a large part of our increased population is due to increased longevity (rather than a high birth rate) does not lessen the impact of the greater numbers. It is irresponsible to preach complacency about population growth and to ridicule those who try to suggest remedies.

$$
\text { Yours faithfully, }
$$

$$
\text { J. M. IOANNOU }
$$

4 Regent Terrace,

Chapel Allerton,

Leeds LS7 4QL

\title{
Obituary
}

\section{Professor J. D. Bernal}

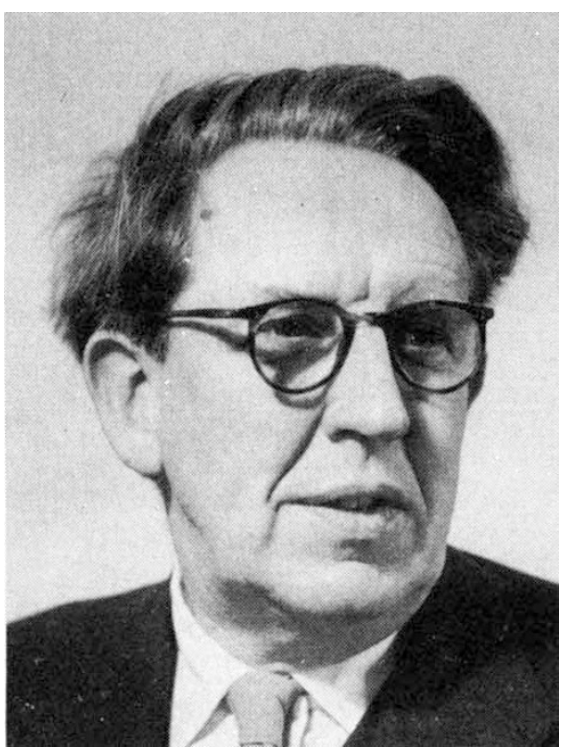

Photo: Henry Grant AIIP

THE recent death of J. D. Bernal, after a long and tragic illness, has robbed British science of one of its most outstanding and controversial figures.

John Desmond Bernal was born seventy years ago in Nenagh, Ireland, the eldest of four children. His father was a Catholic gentleman farmer; his mother a university educated American expatriate and a Protestant. Bernal's background was further variegated by his attendance at English public schools. Partly and paradoxically as the result of this mixture of national and religious traditions, he became a passionate adherent of both Roman Catholicism and Irish nationalism. It was also during this period that Bernal found himself attracted to mathematics and the physical sciences.

His decision to specialize in X-ray crystallography was made during his undergraduate years at Cambridge, so he joined the group of young and brilliant crystallographers that Sir William Bragg had brought together at the Royal Institution. Here, under the general guidance of Bragg himself, and with such workers as Kathleen Lonsdale and W. T. Astbury, he learned the techniques of X-ray crystallography and in 1924 he achieved his first success, using them to determine the structure of graphite. He was in some ways a poor experimentalist, being impatient in a field that required long periods of concentration and accurate measurement. The instrument which was then almost universally employed in British X-ray crystallography, the ionization spectrometer, was slow and tedious, although very accurate, and very early in his experimental career Bernal decided that this method was not for him. This led him to search for simpler, less painstaking methods, which resulted in 1926 in the publication of his first paper of major importanceon the technique of single crystal rotation photography. This paper, which included charts for indexing rotation photographs, made these methods widely available to an English speaking audience for the first time.

In 1927 he returned to Cambridge to a lectureship in crystallography, and it was here that he first began to attract his own scientific followers--Dorothy Hodgkin, I. Fankuchen, M. F. Perutz, and many others. Although he worked on a wide range of substances, in part through contact with the Biochemistry Department he early became interested in biological molecules. Thus, in the thirties, a period of intense political activity, he at the same time did much of his most important scientific work, starting with the sterols, turning to crystalline proteins, and going on to viruses.

In 1932, during a study of the sterols, he was able to demonstrate that the conventional chemical formula for one of these compounds was incorrect, by showing that the size of the molecule from its chemical formula could not possibly fit into the unit cell, the dimensions of which he determined by crystallographic means.

In 1934 he and Crowfoot published the results of work on the crystalline protein, pepsin. Up until this time $\mathrm{X}$-ray work on the crystalline proteins had been held up by the fact that, despite the apparently suitable nature of the crystals, the diffraction effects were in fact highly diffuse, and gave little or no evidence of a highly organized or regular molecular architecture. A number of crystallographers had worked on proteins, but with the exception of fibre workers such as Astbury, little advance had been made. Bernal hit upon the simple expedient of taking pictures of wet rather than dry crystals, and he found that the resultant $\mathrm{X}$-ray photographs included detail down to the atomic level. It was immediately clear that all the necessary detail was present for a full structure determination, if only it could be interpreted.

This work on pepsin, then, laid the foundations for modern protein crystallography, and it posed the questionhow can the detail revealed by the photographs be interpreted? The problem was one well known to all crystallographers - the phase problemalthough made more difficult by the size of the protein molecules. Much of Bernal's later work involved attempts to overcome the phase problem, and although in the end he was ultimately unsuccessful, he offered his co-workers some valuable hints. Thus, in 1939, he suggested two possible approaches, one of which, the isomorphous replacement method, was that successfully employed by Perutz and Kendrew in their work on haemoglobin and myoglobin. Again, he was one of the few crystallographers who really appreciated at an early stage that advanced methods of computing would be needed to process the volume of data involved in protein structure determination, and after the war he organized a research project on automatic methods of calculation.

In 1937 he moved to become Professor of Physics at Birkbeck College, London, and while continuing his protein work he also collaborated with Fankuchen in pioneering work on virus structure and the properties of viruses in solution. His work in pure science was interrupted by the outbreak of war, although he still maintained a lively interest in all crystallographic and biological work.

In post-war years Bernal did much less experimental scientific work himself. This was partly as a result of his wartime administrative experience, and partly because his interests, always wide ranging, were leading him into more general and speculative areas. Thus, while he organized a group at Birkbeck 
to work on proteins, other X-ray work was carried out on a variety of practical problems, the structure of fuel ash, and the hardening of cement, for example. He developed his interest in water, using model building methods in an attempt to understand its structure. At the same time a major part of his energies now involved general biological problems as can be seen in at least two major books, The Physical Basis of Life (1950) and The Origin of Life (1967).

While Bernal did not follow up many of his best ideas, leaving this to others, none the less his own published scientific work was of absolutely major importance. This was recognized in the many scientific honours he received. He was elected a Fellow of the Royal Society in 1937, and in 1945 he was awarded the Royal Medal of the Royal Society. His high standing in the crystallographic community is reflected by the fact that he was President of the International Union of Crystallography from 1963 to 1966 .

Bernal's self-definition as a scientist was exceptionally broad, because it explicitly encompassed ethical and political concerns. In 1923 he joined the Communist Party of Great Britain, with which he was closely associated throughout his life. The period of his most active involvement with politics dates, however, from the early thirties. From then until the outbreak of the Second World War, he helped spearhead a movement of young radical scientists through such organizations as the Cambridge Scientists' Anti-War Group and the Association of Scientific Workers. He was also a prominent participant in the early work of the British Association's Division for the Social and International Relations of Science (founded in 1938). Internationally, Bernal's friendships with socialist researchers in France and the
Soviet Union were instrumental in the foundation of the World Federation of Scientific Workers in 1946. As befitted the breadth of his intellectual interests, the "two cultures" phenomenon hardly affected Bernal, who numbered among his close acquaintances such nonscientists as Benjamin Farrington, Barbara Hepworth, Henry Moore and John Strachey.

Bernal was a thoroughgoing Marxist. His social philosophy, the product of a lifelong dialectic between his ideological beliefs and his professional experiences, was that of scientific socialism. From that vantage point-best summed up in The Freedom of Necessity (1949)-he boldly surveyed man's past in Science in History (3rd ed., 1965) and his possible future in The World, the Flesh and the Devil (1929). But the best-known of his works was The Social Function of Science (1939), a prophetic indictment of the non-use or mis-use of scientific resources in capitalist societies.

In an age of ceaseless warfare, Bernal was above all a partisan of peace. Not being a pacifist himself, his anti-war stance was subjected to the political vagaries of the Cold War. Bernal's attacks on militarized science in the West led to his removal from the Council of the British Association for the Advancement of Science in 1949. $\mathrm{He}$ incurred further enmity for his stand on biological warfare during the Korean War. But he will probably best be remembered for his crucial research on the physics of air raids between 1939 and 1945. The value of his contribution to the Allied war effort was recognized in his appointment as a personal science adviser to Lord Mountbatten. Bernal's dedication to peace has since been commemorated in the establishment of the Bernal Peace Library.

Scientifically and politically, the goals which Bernal set himself were often beyond his reach. Yet when we consider how far his aims transcended those of almost all his contemporaries, we cannot help but admire the audacity and nobility of his life.

Thirty years ago Bernal wrote of the seventeenth-century philosopher Comenius that

"Where he excelled was in having in his own person the knowledge and experience that existed elsewhere scattered in many minds; and in having a burning faith in the practicability of what he propounded. In essence Comenius' mission was a religious one. . . F For him toleration, peace and justice were far more necessary elements of true religion than exhortation or force; education was the means by which it should be spread."

That tribute can now be extended to Bernal himself.

\section{Announcements}

\section{University News}

Dr W. G. Chaloner, University College London, has been appointed to the chair of botany tenable at Birkbeck College, University of London.

Mr P. S. Byrne has been appointed professor of general practice in the University of Manchester, and Mr F. A. Langley has been appointed to a personal chair in obstetrical and gynaecological pathology.

Dr E. M. Symonds, University of Adelaide, has been appointed to the foundation chair of obstetrics and gynaecology in the Medical School of the University of Nottingham.

\section{HOW TO BUY NATURE}

Volumes start in January, March, May, July, September and November, but subscriptions may begin at any time. The direct postal price per subscription is : 12 Months* (52 issues per title)

\begin{tabular}{|c|c|c|c|}
\hline & $\begin{array}{c}\text { Surface mail } \\
\text { UK and } \\
\text { worldwide }\end{array}$ & U.S.A. & Canada \\
\hline Nature (Friday) & $£ 14$ & $\$ 48$ & $\$ 52$ \\
\hline $\begin{array}{l}\text { Nature }+ \\
\text { Nature Physical Science }\end{array}$ & f24 & $\$ 83$ & $\$ 90$ \\
\hline $\begin{array}{l}\text { Nature }+ \\
\text { Nature New Biology }\end{array}$ & $£ 24$ & $\$ 83$ & $\$ 90$ \\
\hline All three editions & $£ 29.50$ & $\$ 108$ & $\$ 116$ \\
\hline Annual Index & $\mathbf{f 1}$ & $\$ 3$ & $\$ 3$ \\
\hline
\end{tabular}

\section{Editorial and Publishing Offices of NATURE}

MACMILLAN JOURNALS LIMITED 4 LITTLE ESSEX STREET, LONDON WC2R 3LF Telephone Number : $01-8366633$. Telegrams : Phusis London WC2R 3LF Telex 262024

711 NATIONAL PRESS BUILDING WASHINGTON DC 20004

Telephone Number : 202-737 2355. Telex 64280 Subscription Department MACMILLAN JOURNALS LIMITED BRUNEL ROAD, BASINGSTOKE, HANTS Telephone Number : Basingstoke 29242 American display advertisements NATURE SCIENTIFIC PUBLICATIONS INC 711 NATIONAL PRESS BUILDING WASHINGTON DC 20004 All other advertisements

T. G. SCOTT \& SON, LIMITED

1 CLEMENT'S INN, LONDON WC2A 2ED Telephone : 01-242 6264/01-405 4743 Telegrams: Textualist London WC2A 2ED

Registered as a newspaper at the Post Office Copyright (C) Macmillan Journals Limited, January 281972 